\title{
Residue determination for some products used against Varroa infestation in bees
}

\author{
M Lodesani 1, A Pellacani 3, S Bergomi 2, E Carpana 1, \\ T Rabitti 3, P Lasagni 2 \\ 1 Istituto Nazionale di Apicoltura, via S Giacomo 9, 1-40126 Bologna; \\ 2 Servizio Veterinario, USL No 9 Reggio Emilia; \\ 3 Presidio Multizonale di Prevenzione, USL No 9, Reggio Emilia, Italy
}

(Received 23 May 1991; accepted 1 April 1992)

\begin{abstract}
Summary - A number of mite infestation control products (Amitraz, Bromopropylate, Fluvalinate, Thymol) were used over a 3-year period (1987-1989) to control Varroa jacobsoni infestation by means of colony treatment in autumn. Treatment was given to 171 hives located in the plains area of the Emilia Romagna region in northern Italy. The residual levels of each product were measured in the honey, wax and adult bees. The samples were taken from each hive in March, May, July and August in the year following treatment. Chemical analysis via gas chromatography showed that: 1), bromopropylate, thymol and fluvalinate persisted in wax samples; 2), bromopropylate and thymol were present in honey samples from the brood chamber. None of the products was found in honey from the supers.
\end{abstract}

varroatosis / chemical control / acaricide / residue / honey / wax

\section{INTRODUCTION}

In a previous article (Lodesani et al, 1990), an examination was made of some therapeutic aspects regarding the use of a number of active ingredients commonly available to control varroatosis in bees (Bromopropylate, Thymol, Amitraz, Fluvalinate).

This study examines residue detection of these substances in bees, honey and wax from the same colonies that were used in the investigation on the effectiveness of the active ingredients. In addition, a number of general health considerations relating to the presence of active ingredients in the considered colony components will also be discussed.

The 4 anti-varroatosis products investigated in our study were chosen for the following reasons: Bromopropylate because it was the only officially authorized drug available when our project was initiated; Amitraz as it was the most commonly used treatment in Italy; Thymol, for its selection in a number of areas due to its 'natural' origins; Fluvalinate as it is the most interesting active ingredient available over the past 2 years and has been authorized for use since 1989. 


\section{MATERIALS AND METHODS}

\section{Field tests}

Treatment with anti-varroatosis products was carried out on 171 colonies of Apis mellifera ligustica during a 3-year period from 1987-1989 in 6 localities in the plains area of the Emilia Romagna Region in northern Italy. The active ingredient (ai) used and the administration methods are summarized in table $\mathrm{l}$.

The colonies used in the tests were homogeneous as regards the number of bees and stocks of food. Care was taken during the last treatment period to ensure that there was an almost total absence of brood.

\section{Acaricide treatments (table I)}

\section{Thymol}

Thymol was used in powder form (Carlo Erba) using the method described by Dettori (1987).

\section{Bromopropylate}

Bromopropylate was used in its commercially available form, Folbex-VA (Ciba Geigy).

\section{Amitraz}

Twenty ml emulsion with $1.6 \%$ Taktic (Schering) were administered to the colonies by aerosol using a diffuser (Edar). Diffusion time for each colony was around $1 \mathrm{~min}$. If a double treatment was given, the second treatment was administered a week after first using the same concentration.

\section{Fluvalinate}

PVC strips (Apistan, Sandoz) were used and inserted in the brood chamber between the 3rd and the 4th and between the 7th and the 8th comb during the autumn of the years covered by our investigation.

\section{Sample collection}

The honey and wax samples were taken from at least 2 combs in each colony: one from the centre and the other from the side. A part of each comb was uncapped with a knife and the honey extracted from the cells with a syringe and placed in test tubes. To remove any impurities, especially particles of wax, the honey was centrifuged at $3000 \mathrm{rpm}$ for $10 \mathrm{~min}$. The wax, which was taken from the caps which had previously been removed, was placed in feeders on the hive comb covers so that the bees could clean

Table I. Active principles used and methods of administration.

\begin{tabular}{|c|c|c|c|c|c|}
\hline \multirow{3}{*}{$\begin{array}{l}\text { Treatments } \\
\text { Active ingredient } \\
\text { (commercial product) }\end{array}$} & $\begin{array}{c}\text { Bromopropylate } \\
\text { (Folbex VA@) }\end{array}$ & Thymol & \multicolumn{2}{|c|}{$\begin{array}{l}\text { Amitraz } \\
\text { (Taktic®) }\end{array}$} & \multirow[t]{2}{*}{$\begin{array}{l}\text { Fluvalinate } \\
\text { (Apistan }())\end{array}$} \\
\hline & \multicolumn{4}{|c|}{ Administration via: } & \\
\hline & Fumigation & Sublimation & $A e$ & ssol & Contact \\
\hline & & & Single & Double & 1 (2 strips) \\
\hline Number & 4 & 3 & 1 & 2 & \\
\hline Interval (days) & 4 & 7 & 1 & 6 & $35-60$ days \\
\hline Dose (mg per colony) & 1480 & $4500-6000$ & 40 & 80 & 1600 \\
\hline Period & Oct-Nov 1987 & Oct-Nov 1987 & Nov 1987 & Nov 1988 & Sept-Nov 1988 \\
\hline & Oct-Nov 1988 & & & & Sept-Nov 1989 \\
\hline
\end{tabular}


off any remaining honey during the following $24 \mathrm{~h}$. Adult bees were taken from the top edge of the brood chamber combs and from the inside face of the comb cover and placed in small cardboard boxes.

Samples were taken at 4 periods during the active season:

- 1st sampling: during the first 10 days of March when the colonies were beginning to develop;

- 2nd sampling: around the middle of May when the first supers were laid;

- 3rd sampling: in July;

- 4th sampling: in August, from the super.

In some cases the 4th sampling was not taken from individual hives, but was made on the honey extracted from all hives in the apiary. During the winter, samples of packaged honey were also taken but only for the ai Amitraz and Fluvalinate. All samples were stored at $-20^{\circ} \mathrm{C}$

\section{Laboratory analysis}

\section{General details}

The majority of analytical methods given in the literature (Formica, 1984; Barbina Taccheo et al, 1985, 1988a,b; Catella et al, 1988; Fabbris et al, 1988; Franchi and Severi, 1989; Torreti et al, 1989) deal with residue assay in honey only. In an attempt to make the methods used as homogeneous as possible, we initially perfected the method for honey which was then modified as needed for use with wax and bees.

Where possible, we chose from the available methods those that called for extraction and purifying in reverse on a Sep-pack cartridge. This route was selected because it was good for the largest number of samples.

We also experimented with an extraction method for Thymol, which had already been tested for phenols on similar matrixes (Daharu and Sporns, 1984).

Method application was checked by experiments using recovery tests for the 4 active ingredients of each of the 3 matrixes. Our method was to add known volume solutions at different concentrations of Bromopropylate, Thymol, Amitraz and Fluvalinate to untreated samples of wax, honey and bees. These matrixes were subjected to the same analysis procedures used with the samples to be analyzed.

Recovery percentages were calculated by comparing the instrument readings for the different standard solutions at various concentrations with the results from the addition of the known volumes of the same solutions. The external standard method was used for the quantitative calculations. Recovery percentage was calculated for each matrix at 3 different active ingredient concentrations (table II).

The sensitivity limit for each ai and matrices was calculated on the basis of the experimental results. In this manner the ai concentration that gave a gas chromatographic peak twice as high as the noise was determined. Sensitivity limits are shown at the foot of each table.

\section{Reagents}

The following reagents were used: acetone for pesticides; $n$-hexane for pesticides; methanol; chloroform; methylene chloride for pesticides; iso-octane for pesticides; $\mathrm{NaOH}$ solution $0.5 \mathrm{M}$; $\mathrm{NaHCO}_{3}$ saturated solution and $0.1 \mathrm{M}$ solution; $\mathrm{NaCl}$ saturated solution; anydrous $\mathrm{Na}_{2} \mathrm{SO}_{4}$; heptafluorobutyric anhyride (HFBA); standard for Amitraz, Fluvalinate, Bromopropylate, Thymol.

The following instruments were used: vacuum system SPE-21 with RP C18 cartridges $0.5 \mathrm{~g}$ and $6 \mathrm{cc}$, (Baker); Omni mixer; Rota vapor (Buchi); 315 distillation unit (Buchi); gaschromatograph HP 5890 with ECD detector and $30 \mathrm{~m}$ and $0.53 \mathrm{~mm}$ id HP5 capillary column; gas-chromatograph HP5890 with MSD 5970 mass detector and $25 \mathrm{~m}$ and $0.2 \mathrm{~mm}$ id ultra 2 capillary column; Nordion gas-chromatograph with 2 EDC detectors and 2 NB54 and NB1701 $25 \mathrm{~m}$ and $0.32 \mathrm{~mm}$ id capillary columns.

\section{Bromopropylate}

The Barbina Taccheo et al method (1985) was used, with some modifications (Formica, 1984; Fabbris et al, 1988; Torreti et al, 1989). 
Table II. Recovery tests.

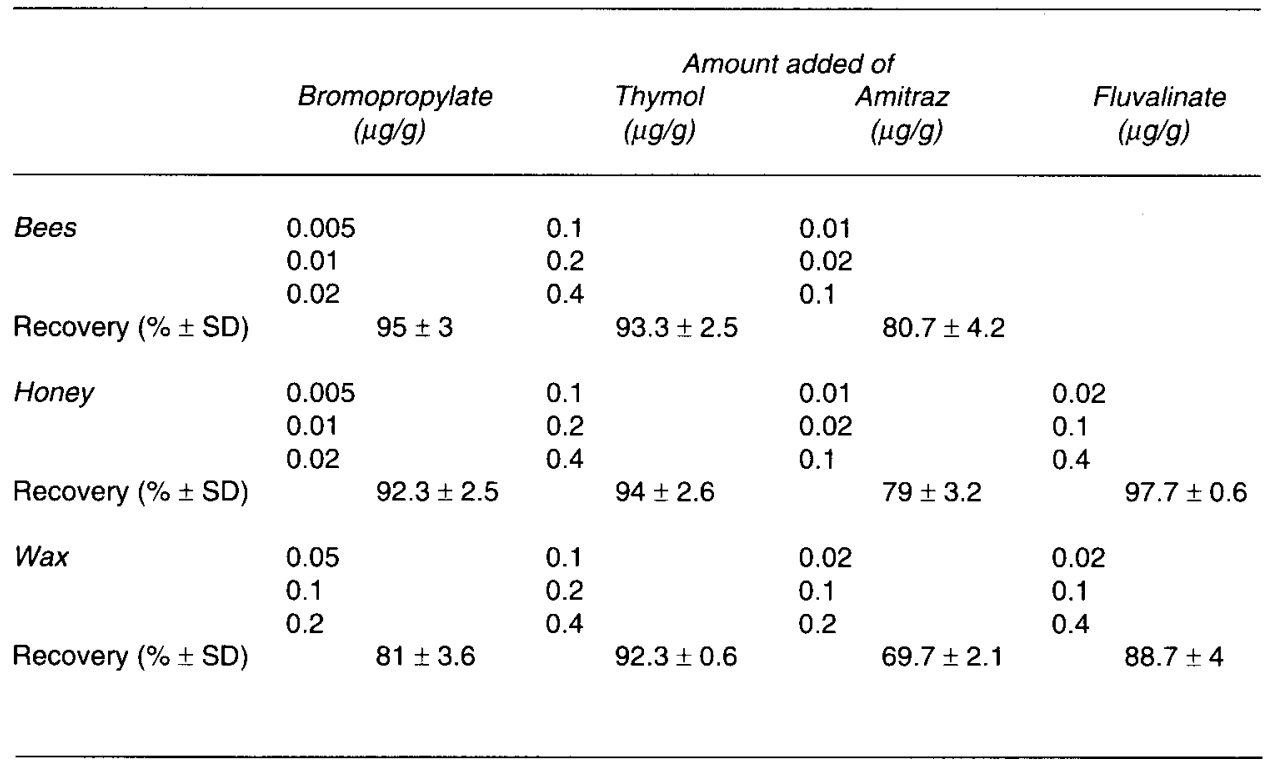

\section{Sample preparation}

\section{Honey}

Five $g$ of the sample were allowed to blend overnight in a beaker with a $10 \mathrm{ml}$ mixture of water/acetone (8:2). The solution was eluted through a previously treated RP C18 cartridge and connected to a vacuum system. The beaker was washed 3 times with $5 \mathrm{ml}$ of water. At the end of the washings, the cartridge was allowed to dry and the ai eluted 3 times with $5 \mathrm{ml} n$ hexane. The extract was concentrated in the rotary evaporator and dried in nitrogen current and added to $1 \mathrm{ml}$ of $n$-hexane for analysis.

\section{Bees}

Five $\mathrm{g}$ of the sample were allowed to blend in a beaker with $10 \mathrm{cc}$ of a water/acetone mixture (8:2) overnight. After filtering the extracts, the same procedure as that used for the honey was followed.

\section{Wax}

Five $\mathrm{g}$ of the sample were allowed to blend with $20 \mathrm{ml}$ of a water/acetone mixture (1:1) for $2 \mathrm{~h}$. After filtering, the same procedure as that used for the honey was followed for the extract and the ai was eluted with $25 \mathrm{ml}$ of $n$-hexane.

\section{Detection}

This was performed by gas-chromatography using an HP 5890 apparatus with an ECD detector and an HP5 column.

\section{Conditions}

The conditions were as follows: initial temperature: $210^{\circ} \mathrm{C}$; rate: $5^{\circ} \mathrm{C} / \mathrm{min}$; final temperature: $270{ }^{\circ} \mathrm{C}$; detector temperature: $300{ }^{\circ} \mathrm{C}$; injector temperature: $220^{\circ} \mathrm{C}$; carrier: helium $(12 \mathrm{ml} / \mathrm{min})$; make-up: $\mathrm{N}(25 \mathrm{ml} / \mathrm{min})(\mathrm{fig} 1)$.

\section{Thymol}

The method used was for all practical purposes that of Daharu and Sporns (1984).

\section{Sample preparation}

\section{Honey}

Five $\mathrm{g}$ of the sample were blended overnight in a beaker with $20 \mathrm{ml}$ of $\mathrm{pH} 5$ acidulated water. The solution was eluted through an RP C18 cartridge connected to a vacuum system and preconditioned with $5 \mathrm{ml}$ of methanol and $5 \mathrm{ml}$ of $\mathrm{pH} 5$ acidulated water. The beaker was washed twice with $5 \mathrm{ml}$ of acidulated water. After washing the cartridge was allowed to dry for $5 \mathrm{~min}$ 


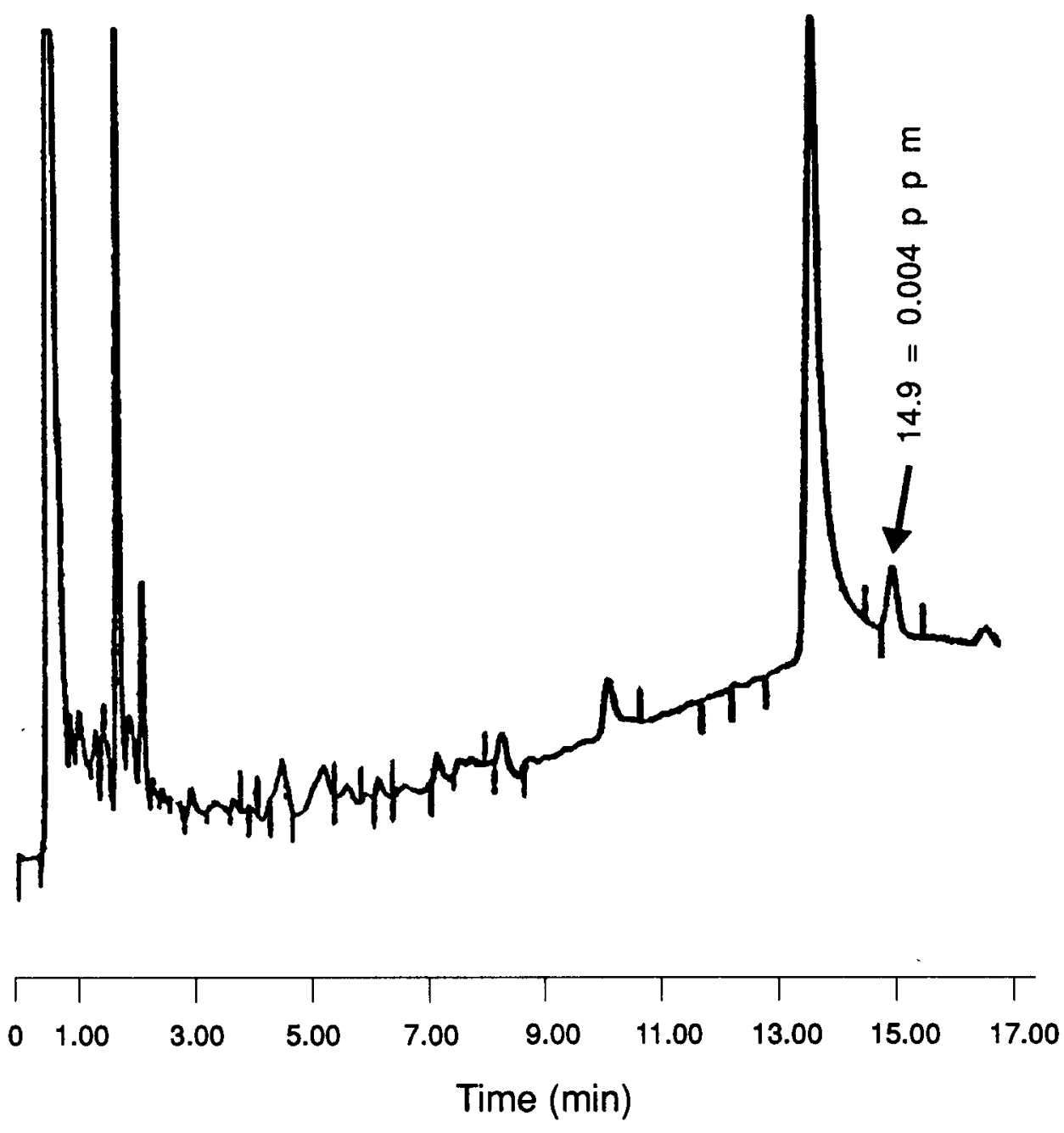

Fig 1. Bromopropylate detection. Chromatogram concerning a honey sample: the arrow indicates the peak corresponding to a concentration of $0.004 \mathrm{ppm}$.

and the ai was eluted 3 times with $5 \mathrm{ml}$ of chloroform. The extract was concentrated in the rotary evaporator, dried in a nitrogen current and added to $1 \mathrm{ml}$ of chloroform for the analysis.

\section{Bees}

The method adopted was the same as that for the honey, the only difference being that the so- lution was filtered before elution through the cartridge.

\section{Wax}

Five $\mathrm{g}$ of the sample were blended in Kjeldahl flasks with $100 \mathrm{ml}$ of distilled water for $1 \mathrm{~h}$. The mixture was steam distilled with a Buchi 315 distiller to obtain $100 \mathrm{ml}$ of distillate. This solution 
was eluted through an RP $\mathrm{C} 18$ cartridge preconditioned with $5 \mathrm{ml}$ of methanol followed by 5 $\mathrm{cc}$ of $\mathrm{pH} 5$ acidulated water.

The flask was washed twice with $5 \mathrm{ml}$ of acidulated water. After washing, the cartridge was allowed to dry for $5 \mathrm{~min}$ and the ai was eluted with $20 \mathrm{ml}$ of chloroform. The extract was concentrated in the rotary evaporator, dried in a nitrogen current and added to $1 \mathrm{ml}$ of chloroform for the analysis.

\section{Detection}

This was performed by gas-chromatography using an HP 5890 apparatus with a mass detector; carrier: helium $(2 \mathrm{ml} / \mathrm{min})$; split: $60 \mathrm{ml} / \mathrm{min}$. Acquisition was by SIM monitoring 91, 135 and $150 \mathrm{~m} / \mathrm{z}$ (fig 2).

\section{Amitraz}

The method adopted detected Amitraz by its total conversion into 2.4 dimethylaniline (Hornish et al, 1984; Barbina Taccheo et al, 1988, 1989; Catella et al, 1988; Franchi and Severi, 1989).

\section{Sample preparation}

\section{Honey}

Five $\mathrm{g}$ of honey were weighed in a scaled test tube and brought to $10 \mathrm{ml}$ with distilled water and shaken until the mixture was homogeneous. Five extractions were then made with $10 \mathrm{ml}$ of $n$-hexane and the organic residues were removed. The extracts were placed in a round-bottomed flask. If an emulsion formed, a few drops of propanol were added and mixed. The extract was concentrated in the rotary evaporator and dried. Two $\mathrm{cc}$ of $\mathrm{NaOH} 0.5 \mathrm{~N}$ were then added and the mixture placed in a thermostat at $95{ }^{\circ} \mathrm{C}$ for $1 \mathrm{~h}$ to obtain total hydrolization. It was allowed to cool, and a further extraction was made with $2 \mathrm{ml}$ of isooctane. One $\mathrm{ml}$ of the organic extract was removed and placed in a screw-cap test tube. A derivatization was made with $5 \mu \mathrm{HFBA}$ by immersing the tip of the syringe in the solution. The sealed test tube was placed in a thermostat at $50{ }^{\circ} \mathrm{C}$ for $30 \mathrm{~min}$ and $1 \mathrm{ml}$ of $\mathrm{NaHCO}_{3}$ saturated solution was added to remove the excess HFBA. The amount required for ai detection was taken from the top of the organic extract.

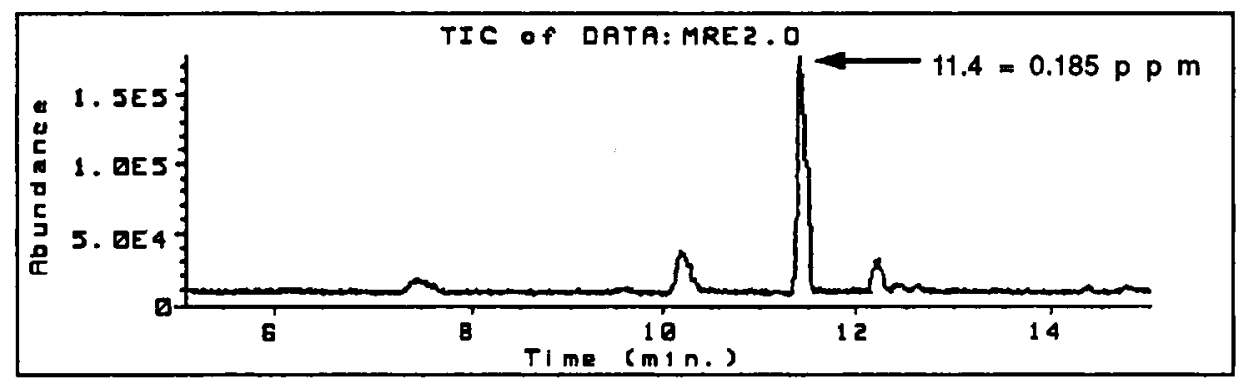

\section{Scan 1059 (11.405 min) of DATA: MRE2.D

$\begin{array}{cccccc}\mathrm{m} / \mathrm{z} & \text { abund. } & \mathrm{m} / \mathrm{z} & \text { abund. } & \mathrm{m} / \mathrm{z} & \text { abund. } \\ 91.00 & 23 & 135.05 & 100 & 150.05 & \dot{28}\end{array}$

Fig 2. Thymol detection. Total ions from a honey sample and relative abundances of $\mathrm{m} / \mathrm{z}$. The arrow indicates the peak corresponding to a concentration of $0.185 \mathrm{ppm}$. 


\section{Bees}

Five $\mathrm{g}$ of the sample were blended with $20 \mathrm{ml}$ of an 8:2 water/acetone solution for $2 \mathrm{~h}$. The extract was filtered through a $125-\mathrm{ml}$ separating funnel and 2 extractions were made with $20 \mathrm{ml}$ of hexane. The organic extract was removed and placed in a round bottom flask. The method was then the same as that described above for the honey sample.

\section{Wax}

The method was the same as that for the bees.

\section{Detection}

Gas-chromatography with a Nordion apparatus was used for detection.

\section{Conditions}

The conditions were as follows: splitless 0.75 ; initial temperature: $50^{\circ} \mathrm{C}$ for $2 \mathrm{~min}$; rate $5{ }^{\circ} \mathrm{C} /$ min to $150{ }^{\circ} \mathrm{C}$ and $10^{\circ} \mathrm{C} / \mathrm{min}$ to $270{ }^{\circ} \mathrm{C}$; final temperature: $270{ }^{\circ} \mathrm{C}$; detector temperature: $300^{\circ} \mathrm{C}$; injection temperature: $220{ }^{\circ} \mathrm{C}$; carrier: helium (1.5 $\mathrm{ml} / \mathrm{min})$; make-up: argon-methane (20 ml/min); split: $15 \mathrm{ml} / \mathrm{min}$; purge: $15 \mathrm{ml} / \mathrm{min}$ (fig 3).

\section{Fluvalinate}

The method used was based on that of Bertona and Sgarzi (1988) and Fitch et al (1988).

\section{Sample preparation}

\section{Honey}

Five $\mathrm{g}$ of the sample were blended with $25 \mathrm{ml}$ of 1:1 water/acetone solution. The solution was eluted through an RP $\mathrm{C} 18$ cartridge connected to a suction system and preconditioned with 5 $\mathrm{ml}$ of methanol and $5 \mathrm{ml}$ of water. The ai was eluted twice with $5 \mathrm{ml}$ of methylene chloride. The extract was concentrated in the rotary evaporator, dried with nitrogen and mixed to $1 \mathrm{ml}$ of hexane for the analysis.

\section{Wax}

Five $\mathrm{g}$ of the sample were blended with $100 \mathrm{ml}$ of methanol and extracts in an Omni-Mixer for $10 \mathrm{~min}$. The extract was filtered through a 500-
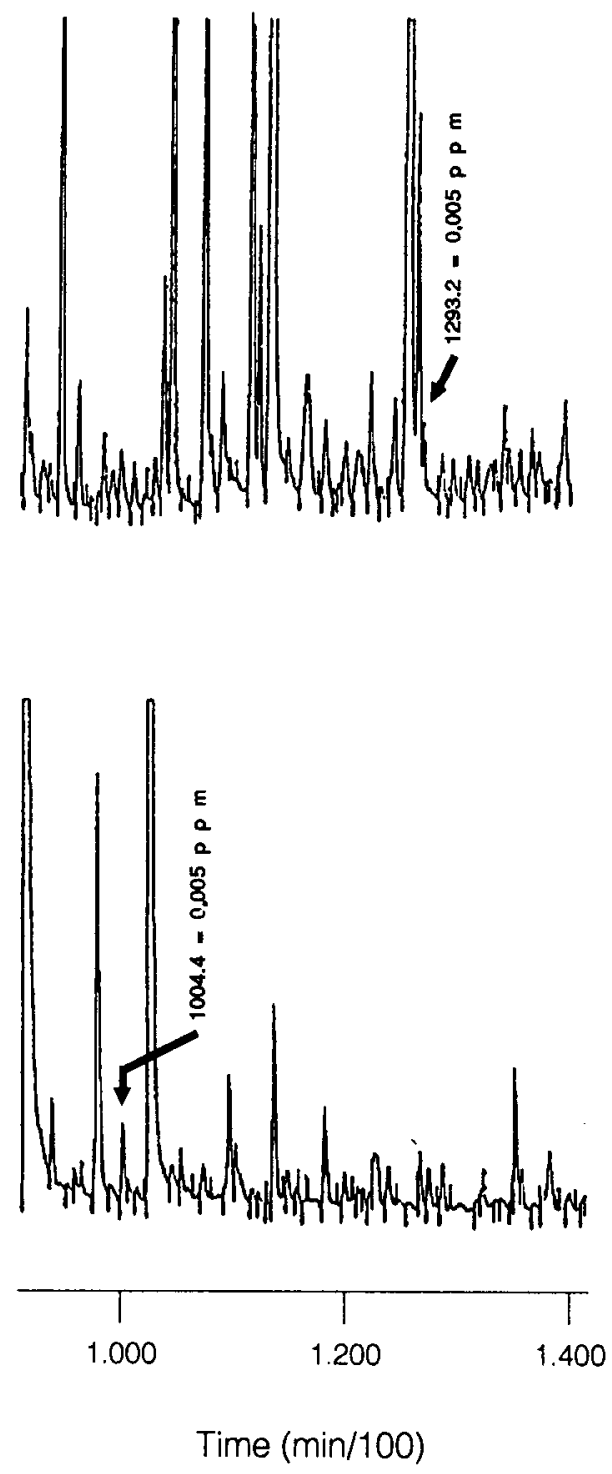

Fig 3. Amitraz detection. Chromatograms concerning a honey sample. Channel 1: NB54 capillary column; Channel 2: NB1701 capillary column. The arrows indicate the peaks corresponding to a concentration of $0.005 \mathrm{ppm}$. 
$\mathrm{ml}$ separating funnel and $200 \mathrm{ml}$ of a $\mathrm{NaHCO}_{3}$ $0.1 \mathrm{~m}$ solution and $5 \mathrm{cc}$ of a saturated $\mathrm{NaCl}$ solution were added. Three extractions were then made with $50 \mathrm{ml}$ of methanol-saturated isooctane and the organic extracts were removed, poured over anhydrous $\mathrm{Na}_{2} \mathrm{SO}_{4}$ and collected in a flask. The extracts were concentrated in the rotary evaporator, dried in nitrogen current and added to $1 \mathrm{ml}$ of isooctane for detection.

\section{Detection}

Gas-chromatography with Nordion apparatus was used for detection.

\section{Conditions}

The conditions were as follows: splitless 0.75 ; initial temperature: $220^{\circ} \mathrm{C}$; rate: $3^{\circ} \mathrm{C} / \mathrm{min}$; final
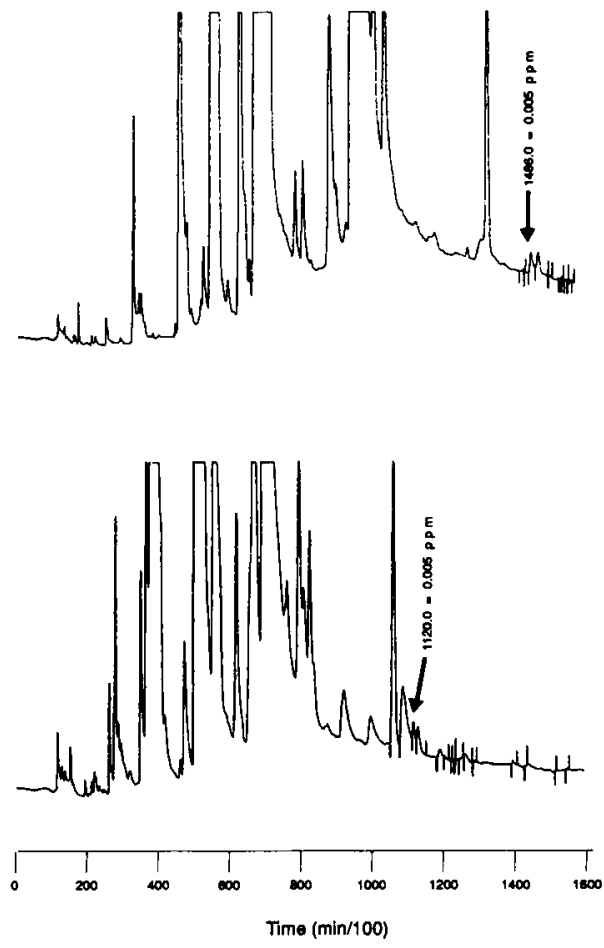

Fig 4. Fluvalinate detection. Chromatograms concerning a wax sample. Channel 1: NB54 capillary column; Channel 2: NB1701 capillary column. The arrows indicate the peaks corresponding to a concentration of $0.005 \mathrm{ppm}$. temperature: $280{ }^{\circ} \mathrm{C}$; detector temperature: $300^{\circ} \mathrm{C}$; injection temperature: $250^{\circ} \mathrm{C}$; carrier: helium $(1.5 \mathrm{ml} / \mathrm{min})$; make-up; argon-methane (20 ml/min); split: $15 \mathrm{ml} / \mathrm{min}$; purge: $5 \mathrm{ml} / \mathrm{min}$ (fig 4).

\section{RESULTS AND DISCUSSION}

Current legislation in Italy on pesticides used in agriculture (Ministry of Agriculture Orders dated 6 June 1985 and 18 July 1990) sets a limit of $0.01 \mathrm{mg} / \mathrm{kg}$ for residues of Amitraz, Bromopropylate and Fluvalinate in products destined for human consumption not specified in schedule 1 and 2 of the second above-mentioned order (honey is among these). Italian law, in particular Law No 753 dated 12 October 1982, Law No 283 dated 30 April 1962 and DPR No 327 dated 26 March 1980, does not allow any ai residue of drugs for veterinary use and also for Thymol.

\section{Bromopropylate}

Our data confirm the results obtained by other researchers (Barbina Taccheo et al, 1988a), ie ai continued to be present in brood chamber honey even a number of months after treatment (table III). The concentration curve for this matrix when compared with that for wax suggested the hypothesis that the ai in the wax was transferred to the honey. The gradual and continuous ai decay in bees was probably due to the progressive turnover of adult bees during the active season.

\section{Thymol}

The levels detected at the first sampling in the hive matrices were higher than those 
Table III. Bromopropylate residues (expressed in ppm).

\begin{tabular}{|c|c|c|c|c|c|}
\hline & & \multicolumn{4}{|c|}{ Sampling } \\
\hline & & \multicolumn{3}{|c|}{ From the brood chamber } & \multirow{2}{*}{$\begin{array}{l}\text { From the super: mixed samples } \\
\qquad N \text { (August) }\end{array}$} \\
\hline & & $I($ March $)$ & /I (May) & III (July) & \\
\hline \multirow[t]{5}{*}{ Bees } & $x$ & 0.017 & 0.012 & 0.006 & \\
\hline & SD & 0.002 & 0.007 & 0.003 & \\
\hline & $\min$ & $<0.001$ & $<0.001$ & $<0.001$ & \\
\hline & $\max$ & 0.079 & 0.025 & 2.245 & \\
\hline & $n$ & 46 & 12 & 8 & \\
\hline \multirow[t]{5}{*}{ Honey } & $x$ & 0.018 & 0.094 & 0.026 & 0.005 \\
\hline & SD & 0.003 & 0.018 & 0.009 & \\
\hline & $\min$ & $<0.001$ & $<0.001$ & $<0.001$ & \\
\hline & $\max$ & 0.077 & 0.245 & 0.070 & \\
\hline & $n$ & 46 & 12 & 8 & 8 \\
\hline \multirow[t]{5}{*}{ Wax } & $x$ & 13.978 & 5.738 & 2.626 & \\
\hline & SD & 0.0993 & 0.551 & 1.028 & \\
\hline & $\min$ & 1.650 & 2.510 & 0.050 & \\
\hline & $\max$ & 34.560 & 8.820 & 8.600 & \\
\hline & $n$ & 46 & 12 & 8 & \\
\hline
\end{tabular}

Limits of determination: $0.001 \mathrm{ppm}$ for honey and bees; $0.05 \mathrm{ppm}$ for wax.

for the other ai tested for in our study (table IV). The fast decrease in concentration in the later samplings could be due to probable thymol sublimation facilitated by the hive microclimate.

As regards wax, following a sharp drop in the values between the first and second sampling (a reduction of about 190-fold) due to the reasons mentioned above, the values stabilized at around $0.2 \mathrm{ppm}$. The high concentrations found at the first sampling can be explained by the high amount of product used in the treatment (from 4.5 to $6 \mathrm{~g}$ ). The quantity of residues in the honey was reassuring: over a period of time they dropped progressively and linearly until, by the 3 rd and 4 th sampling, ai values were below the sensitivity threshold for the analytical method used.

\section{Amitraz}

The honey and wax samples from the 1987 treatment (a single administration) showed the absence 2.4 dimethylaniline (table V). For the 1988 treatment (double administration) 2.4 dimethlylanine was present only in the samples taken in March (table VI). The maximum values detected were $0.012 \mathrm{ppm}$ in the honey and 0.061 $\mathrm{ppm}$ in the wax. The mean for the total samples analyzed was $0.005 \mathrm{ppm}$ for honey and $0.015 \mathrm{ppm}$ for wax. These data 
Table IV. Thymol residues (expressed in ppm).

\begin{tabular}{|c|c|c|c|c|c|}
\hline & & \multicolumn{3}{|c|}{$\begin{array}{l}\text { Sampling } \\
\text { From the brood chamber }\end{array}$} & \multirow{2}{*}{$\begin{array}{l}\text { From the super: mixed samples } \\
\qquad I V(\text { August) }\end{array}$} \\
\hline & & I (March) & II (May) & III (July) & \\
\hline \multirow[t]{5}{*}{ Bees } & $x$ & 0.222 & 0.001 & $<0.001$ & \\
\hline & SD & 0.045 & 0.002 & & \\
\hline & $\min$ & $<0.001$ & $<0.001$ & $<0.001$ & \\
\hline & $\max$ & 1.358 & 0.038 & $<0.001$ & \\
\hline & $n$ & 39 & 11 & 11 & \\
\hline \multirow[t]{5}{*}{ Honey } & $x$ & 0.315 & 0.047 & $<0.001$ & $<0.001$ \\
\hline & SD & 0.315 & 0.045 & & \\
\hline & $\min$ & 0.019 & $<0.001$ & $<0.001$ & \\
\hline & $\max$ & 1.500 & 0.740 & $<0.001$ & \\
\hline & $n$ & 39 & 11 & 11 & 11 \\
\hline \multirow[t]{5}{*}{ Wax } & $x$ & 45.370 & 0.240 & 0.150 & \\
\hline & SD & 5.719 & 0.189 & 0.194 & \\
\hline & $\min$ & 2.540 & 0.078 & 0.057 & \\
\hline & $\max$ & 177.800 & 3.170 & 3.470 & \\
\hline & $n$ & 39 & 11 & 11 & \\
\hline
\end{tabular}

Limits of determination: $0.001 \mathrm{ppm}$ for honey and bees; 0.01 for wax.

were confirmed by the absence of decay products in both the honey of the super and packaged honey. These results confirm the reports of other authors (Celli and Porini, 1987; Barbina Taccheo et al, 1989).

Thus among the ai investigated in our study, Amitraz had the least amount of residue. Any further comments on its advantages in controlling mite infestation in bees will have to wait until its use has been authorized by the Italian Ministry of Health.

\section{Fluvalinate}

No fluvalinate residues were found in honey samples taken at different times (table VII). These results agree substan- tially with those in the literature (Barbina Taccheo et al, 1989; Bogdanov et al, 1990; Borneck and Merle, 1990).

On the other hand, analysis of wax showed the presence and persistence of ai residues. In more detail, data for the samples taken in 2 areas where treatment with Fluvalinate had been carried out (Reggio Emilia and Bologna), though different in quantity, showed a similar trend and high concentrations in the 2nd and 3rd sampling. The values were considerably higher than those reported by Borneck and Merle (1990), though the latter were found under different test conditions. Bogdanov et al (1990) reported higher amounts of residual Fluvalinate than that found in the present study. 
Table V. Amitraz residues after a single treatment (expressed in ppm).

\begin{tabular}{|c|c|c|c|c|c|}
\hline \multicolumn{6}{|c|}{ Sampling } \\
\hline & & $I$ (March) & II (May) & III (July) & $\begin{array}{l}\text { From the super: mixed samples } \\
\qquad I V \text { (August) }\end{array}$ \\
\hline \multirow[t]{4}{*}{ Bees } & $\begin{array}{l}x \\
S D\end{array}$ & $<0.001$ & $<0.001$ & $<0.001$ & \\
\hline & $\min$ & $<0.001$ & $<0.001$ & $<0.001$ & \\
\hline & $\max$ & $<0.001$ & $<0.001$ & $<0.001$ & \\
\hline & $n$ & 12 & 6 & 5 & \\
\hline \multirow[t]{5}{*}{ Honey } & $x$ & $<0.001$ & $<0.001$ & $<0.001$ & \\
\hline & $S D$ & & 0.003 & & $<0.001$ \\
\hline & $\min$ & $<0.001$ & $<0.001$ & $<0.001$ & \\
\hline & $\max$ & $<0.001$ & 0.034 & $<0.001$ & \\
\hline & $n$ & 16 & 11 & 9 & 5 \\
\hline \multirow[t]{4}{*}{ Wax } & $\begin{array}{l}x \\
S D\end{array}$ & $<0.001$ & $<0.001$ & $<0.001$ & \\
\hline & $\min$ & $<0.001$ & $<0.001$ & $<0.001$ & \\
\hline & $\max$ & $<0.001$ & $<0.001$ & $<0.001$ & \\
\hline & $n$ & 12 & 6 & 5 & \\
\hline
\end{tabular}

Limits of determination: $0.001 \mathrm{ppm}$.

Table VI. Amitraz residues after double treatment (expressed in ppm).

\begin{tabular}{|c|c|c|c|c|c|c|}
\hline & & & & Samp & & \\
\hline & & Fro & the brood & mber & From the super & Packaged honey \\
\hline & & $I$ (March) & I (May) & III (July) & IV (August) & $V($ December $)$ \\
\hline Honey & $x$ & 0.005 & $<0.001$ & $<0.001$ & $<0.001$ & $<0.001$ \\
\hline & $\mathrm{SD}$ & 0.001 & & & & \\
\hline & $\min$ & $<0.001$ & $<0.001$ & $<0.001$ & $<0.001$ & $<0.001$ \\
\hline & $\max$ & 0.012 & $<0.001$ & $<0.001$ & $<0.001$ & $<0.001$ \\
\hline & $n$ & 15 & 15 & 15 & 15 & $\leq 8$ \\
\hline Wax & $x$ & 0.015 & $<0.001$ & $<0.001$ & $<0.001$ & \\
\hline & $\hat{S D}$ & 0.004 & & & & \\
\hline & $\min$ & $<0.001$ & $<0.001$ & $<0.001$ & $<0.001$ & \\
\hline & $\max$ & 0.061 & 0.004 & $<0.001$ & 0.004 & \\
\hline & $n$ & 15 & 15 & 15 & 15 & \\
\hline
\end{tabular}


Table VII. Fluvalinate residues (expressed as ppm).

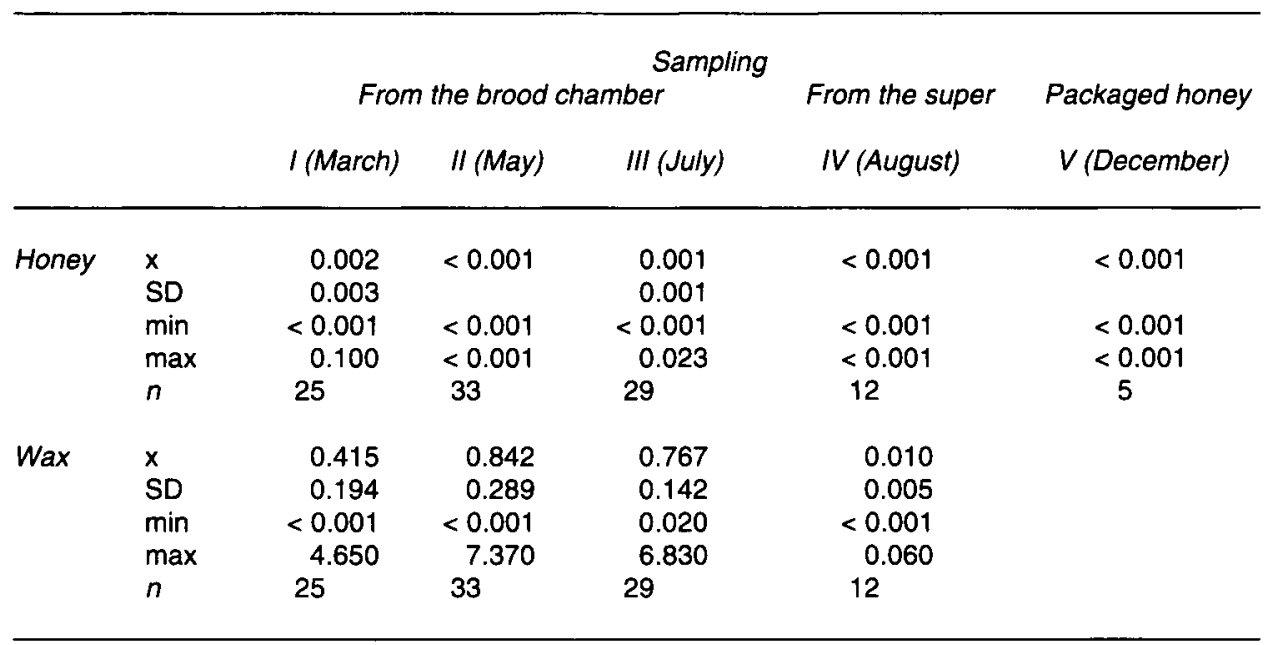

Limits of determination: $0.001 \mathrm{ppm}$.

This ai was also found in the super wax, though to a considerably lesser extent than in the brood chamber wax.

The distribution of the ai between the 2 hive matrices was justified by its very slight solubility in water $(<5 \mathrm{ppb})$, its octane/water partition coefficient (7000-Log $\mathrm{K}=3.8$ ) and its low vapour pressure. Bogdanov et al (1990) reported 2800 to 12 100-folds higher Fluvalinate concentration in wax than in honey from the same sampling. Although ai presence in March can be interpreted as a consequence of the treatment given the previous year, its curve during the summer months is not so easily explained. A possible hypothesis could be increased bee mobility in the brood chamber during the hotter months which would result in increased ai distribution on the comb surfaces. The only other explanation would be chemical interactions of an as yet unknown nature.

\section{CONCLUSIONS}

The chemical analysis of wax demonstrated that Bromopropylate, Thymol and Fluvalinate persisted in almost all the samples. The authors consider that future research projects should examine the negative implications of this, especially as regards the consumption of honey in the comb, the use of this wax in the cosmetics and pharmaceutical industries (suppositories, excipients and various carriers) and its reuse in the beekeeping field.

It is also important to stress that beekeepers should follow correct hive management procedures both as regards the therapeutic treatments used and honey extraction and processing methods. The goal here should be to reduce to minimum levels the amount of wax in the honey by avoiding excessive wax pressing and by 
ensuring that honey was not extracted from brood chamber combs.

In the present state of affairs in Italy, of the chemicals discussed in this study, only Bromopropylate and Fluvalinate are authorized for beekeeping use. The former, though adequate from an effectiveness point of view, has the disadvantage of requiring labour-intensive and frequent administration, is expensive and remains in not inconsiderable residual amounts in the hive matrices.

Fluvalinate is safe and practical to use, quite effective but remains residually for quite some time in wax. The cost of the commercially available product is high. In their study on active ingredient residues in colonies where the strips were left for 13 months, Bogdanov et al (1990) disproved the common opinion that strips are no longer capable of releasing fluvalinate after 4 months because they have been propolized. Furthermore, Moosbeckhofer and Kohlich (1990) have demonstrated that fluvalinate continues to be anti-mite effective in the hive even some months after the strips have been removed.

However, the fact that it requires just a single administration and the way in which it works tend to induce the beekeeper to become negligent, ie he is convinced that if the strips are left for a longer period, the drug will continue to perform its task and therefore does not remove them at the prescribed times.

Another important consideration is the presence of the active ingredient in wax at sub-lethal concentrations for mites and for such long periods of time as to induce drug-resistant strains due to the ongoing presence of the drug on a matrix in close contact with both bees and mites.

In the future, though its effectiveness depends on how it is administered and in what quantities, Amitraz deserves more attention especially as it leaves no residue in hive products.
The problem of water soluble coformulants in the commercially available product still requires in-depth investigation since due to their chemical make-up, these substance have a higher affinity towards honey.

Though interesting because of its low price, in our study Thymol did not achieve the therapeutic efficiency results called for by the current epidemiological situation. In fact, not even the residue analysis results would lead us to recommend this product.

The next stage in our research efforts will be to analyze the honey and wax samples from colonies treated with Fluvalinate and taken at 30,60 and 90 days from the date the strips were placed in the hives. This same set of experiments will look into any products of Fluvalinate denegeneration.

Résumé - Détermination des résidus de quelques acaricides utilisés contre la varroatose. Pendant une période de 3 ans, de 1987 à 1989, des expériences ont porté sur des acaricides utilisés contre Varroa jacobsoni: le bromopropylate, le thymol, l'amitraze et le fluvalinate (tableau I). Les traitements ont été réalisés à l'automne sur 171 colonies situées dans des localités de la plaine d'Italie du Nord. Pour le bromopropylate et le fluvalinate, on a respectivement utilisé le Folbex $\mathrm{Va}^{\circledR}$ (Ciba Geigy) et l'Apistan ${ }^{\circledR}$ (Sandoz) selon les modalités prescrites par les firmes; pour l'amitraze, le Taktic $^{\circledR}$ (Schering), appliqué en aérosol en traitements uniques ou répétés. Le thymol a été utilisé en cristaux (Carlo Erba) en traitement direct sur des cadres couverts d'abeilles. On a déterminé les résidus de chaque matière active (MA) dans des échantillons de miel, de cire et d'abeilles adultes prélevés dans chaque colonie à 4 reprises (mars, mai, juin et août). Les analyses ont été effectuées par chromatographie en phase gazeuse. Le ta- 
bleau II présente les résultats des tests de récupération de chaque MA utilisée.

Le bromopropylate a laissé des résidus supérieurs aux limites admises dans le miel du corps de ruche et surtout dans la cire, où les valeurs sont restées encore élevées même plusieurs mois après le traitement (tableau III, fig 1). Le thymol a été retrouvé en quantités très élevées dans les différents échantillons, mais uniquement dans les premiers prélèvements. Par la suite, les valeurs ont baissé sensiblement (tableau IV, fig 2). En ce qui concerne l'amitraz, les valeurs moyennes du 2,4diméthylaniline déterminées dans chaque prélèvement ont presque toujours été nulles (tableau $V$, fig 3), même après un double traitement (tableau VI). Le fluvalinate n'a pas laissé de résidus dans le miel. Par contre, des quantités non négligeables ont été retrouvées dans la cire (tableau VII, fig 4). L'analyse des échantillons de miel prélevés dans les hausses a donné un résultat négatif pour toutes les MA utilisées.

On souligne la nécessité d'appliquer les acaricides suivant les modes de traitement appropriés. Leur utilisation correcte ne comporte, en effet, aucun risque de pollution du miel destiné au commerce. Toutefois, les résidus retrouvés dans les échantillons de cire ne sont pas, en règle générale, rassurants. II convient par conséquent d'approfondir ce dernier aspect pour vérifier les conséquences défavorables, surtout en ce qui concerne l'utilisation de la cire dans les industries cosmétique et pharmaceutique, ainsi que sa réutilisation dans le secteur apicole.

Varroatose / lutte chimique / acaricide / résidu / miel / cire

\section{Zusammenfassung - Rückstandsbe- stimmung von einigen benutzten Pro-}

dukten in der Varroatosebekämpfung. In den drei Jahren von 1987 bis 1989 wurden die folgenden Akarizide zur Bekämpfung der Varroatose getestet: Brompropylat, Thymol, Amitraz, Fluvalinate (Tabelle I). Die Anwendung wurde im Herbst bei 171 Völkern in der norditalienischen Tiefebene vorgenommen. Bromopropylat und Fluvalinate wurden in Form der Handelspräparate Folbex VA (Ciba Geigy) und Apistan (Sandoz) nach den Angaben der Hersteller angewendet. Für Amitraz wurde Taktic (Schering) als Aerosol einmalig oder wiederholt angewendet. Thymol wurde in Kristallform (Carlo Erba) direkt auf die von den Bienen bedeckten Waben aufgebracht. Für jeden Wirkstoff wurde eine Rückstandsbestimmung in Stichproben von Honig, Wachs und erwachsenen Bienen vorgenommen. Aus jedem Volk wurden vier Mal Stichproben entnommen, und zwar in den Monaten März, Mai, Juli und August. Die Analysen sind mit Gaschromatographie ausgeführt worden. Die Wiedererlangungsproben für jeden Aktivstoff sind in Tabelle 2 zusammengestellt. Die Rückstände von Brompropylat lagen beim aus Brutraum entnommenem Honig und vor allem bei Wachs, wo sie auch mehrere Monate nach der Behandlung noch erhöht waren, oberhalb der zulässigen Grenzwerte (Tabelle III, Abb 1). Thymol wurde in allen drei Komponenten nur in den ersten Stichproben in hohen Mengen gefunden. In den anschließenden Stichproben waren die Werte merklich gesunken (Tabelle IV, Abb 2). Was die Rückstände von Amitraz betrifft, fielen die bei jeder Stichprobe vorgenommenen durchschnittlichen Bestimmungen von 2,4Dimethylanilin fast immer negativ aus (Tabelle $\mathrm{V}, \mathrm{Abb} 3$ ), auch nach einer doppelten Anwendung (Tabelle VI). FluvalinatRückstände im Honig wurden nicht gefunden. Im Wachs konnten dagegen signifikante Mengen dieses Wirkstoffes gefun- 
den werden (Tabelle VII, Abb 4). Die Untersuchung des aus dem Honigraum entnommenen Honigs hat für alle hier in Betracht gezogenen Wirkstoffe stets negative Resultate erbracht. Es wird unterstrichen, daß alle Milbenbekämpfungsmittel unbedingt nach den vorgeschriebenen Methoden angewendet werden müssen. Bei korrekter Anwendung dieser Präparate besteht keine Gefahr, daß der für den Handel bestimmte Honig Schadstoffrückstände aufweist. Die in der Mehrzahl der Wachsstichproben gefundenen Rückstände sind jedoch besorgniserregend. Dieser Aspekt sollte daher noch eingehender untersucht werden, vor allem in Hinsicht auf die Auswirkungen der Wachsverwendung in der Kosmetik und Pharmaindustrie, sowie bei der Wachswiederverwendung in der Bienenzucht.

\section{Varroatose / chemische Bekämpfung / Akarizide / Rückstand / Honig / Wachs}

\section{REFERENCES}

Barbina Taccheo M, De Paoli M, Spessotto C, Marchetti S (1985) Metodo multiresiduo per la determinazione nel miele di alcuni principi attivi impiegati contro Varroa jacobsoni Oud. In: Ve Simp Chim Antiparassitari - Residui Metaboliti e Prodotti di Trasformazione, Piacenza, 1985. Biagini, Lucca, (I)

Barbina Taccheo M, De Paoli M Marchetti S, D'Agaro M (1988a) Bromopropylate decay and residues in honey samples. In: Eur Res Varroatosis Control. Proc Meet EC Experts' Group, Bad Homburg, 1986. AA Balkema, Rotterdam, 131-144

Barbina Taccheo M, De Paoli M, Spessotto C (1988b) Determination of total Amitraz residue in honey by electron capture capillary gas chromatography - a simplified method. Pestic Sci 23, 59-64

Barbina Taccheo M, De Paoli M, Barbattini R, Chiesa F, Milani N, D'Agaro M (1989) Residues in hive products of chemicals used to control Varroa jacobsoni Oud. In: Present Status of Varroatosis in Europe and Progress in the Varroa Mite Control. Proc Meet EC Expert's Group, Udine, 1988. Office Official Pub European Communities, Luxembourg, 369377

Bertona A, Sgarzi B (1988) Caratteristiche chimico-fisiche, tossicologiche ed attività biologica di fluvalinate, nuovo insetticida piretroide. Atti Giornate Fitopatol, Bologna 1988. CLUEB, Bologna (I) 2, 325-334

Bogdanov S, Imdorf A, Kilchenmann V, Gerfig L (1990) Rückstande von Fluvalinat in Bienenwachs, Futter und Honig. Schweiz BienenZeitung 113, 130-134

Borneck R, Merle B (1990) Essais sur Apistan en 1988. Apiacta 25, 16-25

Catella G, Ferrari M, Sermini A, Trinci G (1988) Determinazione del contenuto di Amitraz nei mieli-Elaborazione di un metodo analitico Studio di una sperimentazione. Boll Chim /gien $39,23-43$

Celli G, Porrini C (1987) Amitraz, finalmente dosati i residui. Ecco un-indagine tutta italiana. Apitalia 14, 5-6

Daharu P, Sporns P (1984) Evaluation of analytical methods for the determination of residues of the bee repellent, phenol, in honey and beeswax. J Agric Food Chem 32, 108-111

Dettori A (1987) Efficace il timolo polverizzato nella lotta alla varroa. Apitalia 14 (3-4), 19-21

Fabbris F, Rogeldi R, Contorni C, Palma R (1988) Determinazione del bromopropilato nel miele con metodo gascromatografico. Ind Aliment 27, 551-553

Fitch W, Sjolander A, Wayne MW (1988) Determination of Fluvalinate metabolite residues in cotton seed, apples, tomatoes and soil. $J$ Agric Food Chem 36, 764-766

Formica G (1984) Gaschromatographic determination of residues of Bromopropylate and two of its degradation products in honey. $J$ Assoc Off Anal Chem 67 (5), 896-898

Franchi A, Severi A (1989) Comportamento dell'Amitraz e dei suoi prodotti di degradazione nel miele. VIle Simp Chim Antiparassitari, Piacenza, 1989. Biagini, Lucca (I), 89-96

Hornish R, Clasly M, Nappier JL, Nappier JM, Hoffman GA (1984) Total residue analysis of Amitraz. Residues in fruit and soil samples by electron capture gas chromatography. $J$ Agric Food Chem 32, 1219-1223 
Lodesani M, Bergomi S, Pellacani A, Carpana E, Rabitti T (1990) Prove sperimentali per la valutazione dell' efficacia e per la determinazione dei residui di alcuni prodotti impiegati nella lotta alla varroasi. Apicoltura 6, 105130

Ordinanza Ministeriale (1985) 6 June 1985; Gazz Uffic Repubb Italiana 250, 23 October 1985

Ordinanza Ministeriale (1990) 18 July 1990, Gazz Uffic Repubb Italiana 202 (Suppl Ordinario), 30 August 1990
Moosbeckhofer R, Kohlich A (1990) Nachwirkung von Apistan nach der Entfernung der Streifen. Bienenvater 111 (1), 3-9

Torreti L., Simonella A, Calvarese S, Di Francesco $C$, Filipponi $C$, Scacchia M, Simonella $G$ (1989) Gas-chromatographic survey of Bromopropylate residues in honey produced in Abruzzi (Central Italy). In: Present Status of Varroatosis in Europe and Progress in the Varroa Mite Control. Proc Meet EC Experts' Group, Udine, 1988. Office Official Pub European Communities, Luxembourg, 387-392 